\title{
GOOD GOVERNANCE AND THE EMERGENCE OF A PUBLIC SPHERE: \\ Gazing Upon the Reform of Islamic law in Indonesia
}

\author{
By: Muhammad Latif Fauzi ${ }^{*}$
}

Abstrak

Tulisan ini menyorot fenomena good governance dikaitkan dengan munculnya ruang public (public sphere) di tengah-tengah masyarakat Indonesia. Penulis mengambil kasus gagasan Counter Legal Draft Kompilasi Hukum Islam dan berbagai corak reaksi dan respon masyarakat sebagai contoh ruang publik yang patut diapresiasi. Sebagai kesimpulan, dapat dikatakan bahwa ketersediaan ruang publik tidak lebih dari sekadar penciptaan iklim/atmosfir yang kondusif dan kokoh untuk melanjutkan agenda pembangunan good governance yang masih belum berjalan seutuhnya.

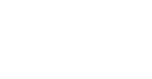

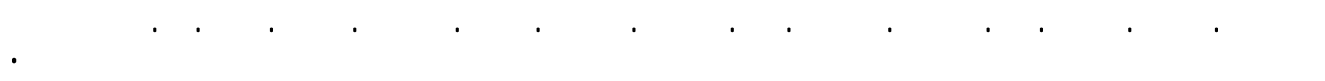

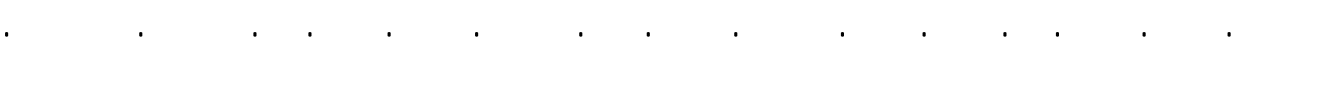

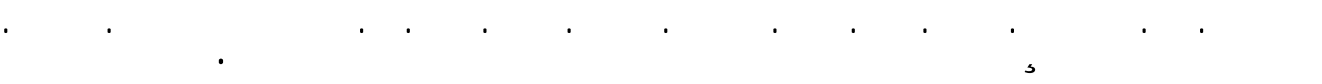

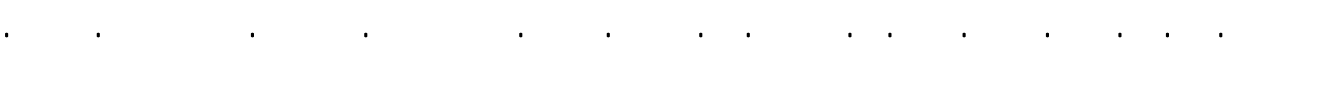 . .}

Keywords: good governance, public sphere, Islamic law reform, the CLD of KHI

\section{A. Introduction}

In recent years an intensified discussion concerning good governance has arisen in many developing countries. In many cases in various countries, this situation is triggered by successfully managing the transition from military rule, military socialism and ethno-nationalist dictatorship to multi-party democracies. In Indonesia, in which the democratization is still on going process, today

${ }^{*}$ He obtained his MA from the Post Graduate Programme of the State Islamic University Sunan Kalijaga Yogyakarta in 2006. He is presently taking his second MA in Islamic Studies at the Institute for Languages and Cultures of the Middle East, Leiden University, the Netherlands. 
attempts are being undertaken by the government to deal with national institution building. There is a real wish of society for fighting corruption and nepotism and creating clean and good governance. A hope of a better economic condition and the reform in legal and judicial sector is persistently voiced. ${ }^{1}$

However, those desires are not easy as they sound to be implemented. Although President Soeharto has reigned in May 1998, the New Order did not end. This is what Daniel S. Lev wrote in his article "Reformasi?." To what extent does his statement give a meaning? It is indeed true that only a little was done during the reform process in Indonesia instead of the widespread demand for political and legal reforms during the early New Order and the promise of the new regime that it would bring about such reforms. Subsequently, the political reform is a less likely agenda to do. To mention, courts, police and most bureaucratic offices which should be autonomous based on legal process are now deeply asleep in corruption practices. ${ }^{2}$

Apart from that, it is generally recognized that discussion on good governance is large and all encompassing. Nonetheless, everyone will have an assumption that establishing good governance in Indonesia requires not only encouraging and sustaining market competition in the economic sector or promoting efficient, accountable and transparent public administration but also participation of citizens in each state's policy making process. ${ }^{3}$ For the last, the participation does not merely mean taking a part in a political sector through democratic institutions, such as such as free and fair elections, political parties and parliaments. Yet, it is intended to people participating in civil society organisations and advocacy groups which become an effective instrument for influencing policies and overseeing government performance. ${ }^{4}$

\footnotetext{
${ }^{1}$ See Dewi Fortuna Anwar (2001), "Pluralism and Good Governance" in International Journal on Minorities and Group Rights 8, pp. 17-18.

${ }^{2}$ Daniel S. Lev (2000), "Reformasi?" in Andi Faisal Bakti (ed), Good Governance and Conflict Resolution in Indonesia, Jakarta: Logos, p. 15.

${ }^{3}$ Asian Development Bank (1999), "Good Governance and Anti Corruption: The Road Forward for Indonesia", paper presented at the $8^{\text {th }}$ Meeting of the Consultative Group on Indonesia, Paris 27-28 July, pp. 3-5.

${ }^{4}$ For a comparison in Beirut, see Daniel Genberg (2002), "Public Space Inside Out: Beirut's Private and Public Spaces Under Reconstruction," in Eva Poluha and Mona Rosendahl,
} 
In this paper, I want to talk over the issue of good governance with focusing on participation of people in the process of Islamic law reform, especially family law, in Indonesia. In a more concrete way, I shall address good governance by concerning the public sphere emerging among Indonesian society which accompanies state's decision making process. For this interest, the issuance of the Counter Legal Draft of Kompilasi Hukum Islam offered by the Team of Gender Mainstreaming which was very controversial and 'successful' to invite people to react becomes my point of departure in this discussion. First of all, this paper starts with an overview on the proposal for Islamic law reform in Indonesian and the necessity for a public sphere. Afterwards is a brief description of the CLD of KHI and some responses upon the draft which basically can be considered as an emerging public sphere. A small discussion about this phenomenon and concluding remarks will end this paper.

\section{B. The Reform of Islamic Law in Indonesia and the Requisite for a Public Sphere}

In connection with the proposals for Islamic law reform in Indonesia, at the very beginning writer's view, what has walked in the last fife years and is walking now shows us that how this reform still seems pleasing and satisfying. The Islamic law development in Indonesia which hitherto has passed many phases since the era of kingdom powers, the colonial era, the independence era including Old Order and New Order and the era of reformation as nowadays ${ }^{5}$, has been and always is nuanced by calls for the reformation. At least, twenty years ago in 1985 it started formally with legislating and codifying shari'a. ${ }^{6}$ However, throughout its process the reform is always coloured by the emergence of conflicts and tensions.

Contesting Good Governance: Crosscultural Perspectives on Representation, Accountability and Public Space, London: Routledge Curzon, pp. 239-242.

5 Khoiruddin Nasution (2002), Status Wanita di Asia Tenggara: Studi terhadap Perundang-undangan Perkawinan Muslim Kontemporer di Indonesia dan Malaysia [the Status of Women in South East Asia: A Study of the Muslim Contemporary Marriage Laws in Indonesia and Malaysia], Jakarta: INIS; Marzuki Wahid and Rumadi (2001), Fiqih Mazhab Negara: Kritik atas Politik Hukum Islam di Indonesia [State Fiqh: A Critique of Islamic Politic Law in Indonesia], Yogyakarta: LKiS,.

${ }^{6}$ John R. Bowen (2003), Islam, Law and Equality in Indonesia: An Anthropology of Public Reasoning, Cambridge: Cambridge University Press, especially in the part 3, Governing Muslims through Family. 
A very clear indication of this symptom is an emerging discursive conflict between those who call for reform on the one hand and those who still want to keep the Islamic law remaining as its originality and established until today on the other. $^{7}$

The issue of reformation evaporates again mainly when in 2000 the law number 25 on the Program of National Development was issued. This law demanded the status of the Presidential Instruction number 1 year 1991 on the Promulgation of Kompilasi Hukum Islam (the Compilation of Islamic Law) to be raised as a law. Besides that, research done by the Directorate of Religious Courts Monitoring of the Ministry of Religious Affairs (MORA) in 2001 reported that it is almost one hundred percents implicitly and about seventy one percents explicitly that the judges of Religious Courts and Religious Appeal Courts make Kompilasi Hukum Islam (for the next I call it the Compilation) as a main source and a law basis in their decisions.

With regard to the demand for the law and the effectiveness of the Compilation, since 2002 the Directorate of Religious Courts Monitoring on behalf of the Ministry of Religious Affairs has been attempting to make the Compilation as the bill of Applied Law of Religious Court in Marriage and Endowment. This bill is an effort of government to raise the status of Islamic marriage law from the President's Instruction level to the law level.

Considering this situation, a reformist intellectual group on behalf of the Team of Gender Mainstreaming $(\mathrm{TGM})^{8}$ did research, a discussion, arranged a reformulation of material law within KHI and created an alternative draft of the Compilation. This draft is called 'the Counter Legal Draft of Kompilasi Hukum

7 The development of family law in Muslim countries can be classified into three categories: 1) countries in which the classic family law remains unchanged, 2) countries which replace fiqh family law with modern legislation, and 3) countries in which only are some parts of the law reformed and legislated. Tahir Mahmood (1972), Islamic Law Reform in the Muslim World, Bombay: Triphathi Pvt, pp. 2-3.

${ }^{8}$ This team claiming as a team work under the Ministry of Religious Affairs is leaded by Siti Musdah Mulia, a Professor at Islamic State University of Syarif Hidayatullah Jakarta. There are 11 people as members of this team. They are Marzuki Wahid, Abdul Moqsith Ghazali, Anik Farida, Saleh Partaonan, Ahmad Suaedy, Marzani Anwar, Abdurrahman Abdullah, KH. Ahmad Mubarok, Imam Nakhoi, Amirsyah Tambunan, and Asep Taufik Akbar. Tim Forum (2004), "Poligami, Jangan... Kawin Kontrak, Silakan...," [Polygamy, No...Contract Marriage, Please] in FORUM Keadilan, no. 26, 24 October, p. 15. 
Islam'. Their study of the Compilation is based on a point of view that is if looked form its content, the existed Compilation is very conservative and does not fit to the reality of Indonesian society. If looked from feminist perspective, especially aspect of gender equality, there are some sections and articles which are not suitable for gender justice aspiration. ${ }^{9}$

As a result, the TGM on Monday, 4 October 2004 issued their draft. In the Counter Legal Draft, there are some important changes in connection with marriage law, such as the definition of marriage, guardianship in marriage, state registration, minimum age of marriage, bride-price, inter-religious marriage, polygamy or polyandry, right of wife to divorce and remarriage, 'iddah, ihhdâd, agreement of marriage, nusyûz, and so forth. ${ }^{10}$

It had got various responses and raised some controversies. For a part of people, the Compilation does not need to be revised because it has been hand in hand with the real condition of Indonesian community. In spite of that, some others argue that the Compilation is not appropriate with the development of society. In their perspective, every text necessarily needs a renewal otherwise it will be leaved by society.

The Indonesian recent debate gives a signal to us on how progressive the spirit to reform both content and status of family law. The emergence of intellectual conflict and academic tension along with a complex and long process of codification of Islamic family law, especially after the New Order regime, should be analyzed as a process of consciousness building of political power and public society in raising a democratic life. This matter does not simply relate to the domain of politic between executive and legislative as usually happens in other legal problems, but also connects with the social discourse.

\section{The Counter Legal Draft of Kompilasi Hukum Islam as a Case}

${ }^{9}$ An interview by Ulil Abshar Abdalla with Siti Musdah Mulia. See Siti Musdah Mulia, "Kompilasi Hukum Islam Sangat Konservatif!" [the Compilation of Islamic Law is Very Conservative!] in http://islamlib.com/id/index.php? page=article\&id=408, accessed on 7 September 2005.

${ }^{10}$ Kompas Newspaper, 11 October 2004. 
The historical development of social economy and politic does not run linearly on a rigid pattern. Social realities in the contemporary world tend to be wider and more open. Job distribution among husbands and wives, males and females has changed and not stood on the stagnant rhythm. Nowadays, both of them can move on the same domain. Women do not necessarily limit themselves to work in the domestic sector and on the contrary men in the public area. Hence, the function of family economy pillar is not only on the monopoly of husbands, but also of wives. These factual shifting walk very quickly and to what extent influence the relationship pattern of human being. They are also influenced by a more opened access for women in an educational sector. This reality surely and insistently requires one condition that intellectuality and intelligence level of women are not below men's. Thus, claim of superiority of men as a natural gift from God is not completely right. ${ }^{11}$

Islamic law formulated in classic fiqh, especially family law, which provides a set of the so called should-be-norms ought to be able to address and be adaptive to this situation. The emerging questions are: Must the tenets of Islamic law $^{12}$ be kept strictly and consequently ulama' leave society and its changes without any legal solution? Must the socio cultural condition which has changed rapidly be judged by the same law as it was firstly founded by ulama' individually or in a certain school?

Based on the above reason and provoked by the glowing movement of family law reform in Muslim countries since the twentieth century, the Team of Gender Mainstreaming (TGM) simultaneously issued the Counter Legal Draft of Kompilasi Hukum Islam. This is an alternative draft of the Compilation which for

${ }^{11}$ A source mentions that an educational access level of women in Indonesia has moved upwards though it is sill worrying compared to men's access. As an example, the ratio of women from men in graduation at senior high school is 92.8 percents in 2002 . The ratio of illiteracy in 1999 is 5.3 percents form women and 2.7 percents for men. Women are also at the biggest number looked from the uneducated twenty four years old people, 17.39 percents for women and 7.68 percents for men. This data is cited from Fajar Newspaper, 9 March 2006.

${ }^{12}$ The term of Islamic is used generally to refer aspects of shari'a. After independence in the most Muslim country, the term of Islamic law is specified and limited referring to the family law issues. Abdullah Ahmed an-Nai'm (2002), "Shari'a and Islamic Family Law Transition and Transformation," in Islamic Family Law in a Changing World: A Global Resource Book, Abdullah Ahmed an-Na'im, ed., London: Zed Book, p. 2. 
the most part uses gender and feminist approach. According to the team, the inquiry and reformulation of the Compilation hold by them in a more specific logic is based on a rationale that both in existential and substantial outlook, the Compilation is not capable enough to deal with many complex social problems. ${ }^{13}$ Moreover, the Compilation has a basic weakness in its vision and mission. Some sections in the Compilation contradict Islamic principles taught literally in the Qur'an, such as equality (al-musâwah), brotherhood (al-ikhâ'), justice (al-`adl), mashlahat, human right, pluralism (al-ta'addudiyah), and gender equality. There are a number of sections in the Compilation which are gender biased. ${ }^{14}$ These sections should be eliminated so any actions to marginalize and discriminate against women are not formally institutionalized in the rule of law. ${ }^{15}$

Besides that, from the historical perspective, the Compilation was a product of government's policy which had been formulated based on the Islamic normative law, mainly the school of Shâfi'î. Therefore, it appears in an uncommon form compared to the national and international legal system that has a strong commitment to create an egalitarian, plural, and democratic society. Even, some Muslim thinkers indicate that sections in the Compilation contain potentials to hinder the ongoing process of democratization in Indonesia. ${ }^{16}$

As a further implication, the Compilation was impressed as a law product which is not parallel with other positive laws. In the Indonesian context, it contradicts some other laws, such as the Law number 7/1984 Elimination of All Forms of Discriminations against Women, the Law number 39/1999 on the Human Rights that emphasizes to protect and strengthen women's position. In the international context, $\mathrm{KHI}$ is also not in line with CEDAW (the Convention on the Elimination of All Forms of Discrimination against Women), and other

${ }^{13}$ Tim Pengarusutamaan Gender (2004), Pembaruan Hukum Islam: Counter Legal Draft Kompilasi Hukum Islam [the Renewal of Islamic Law: the Counter Legal Draft of Kompilasi Hukum Islam], Jakarta: Depag RI, p. 7.

${ }^{14}$ According to Siti Musdah Mulia, one example of them is the position of husband and wife as ruled in the section 79. It is mentioned that a husband is the head of a family. This section has shaped a social norm to place a domestic rule on the hand of women. A man is a leader and a woman is leaded by the man.

${ }^{15}$ Abd Moqsith Ghazali (2005), “Argumen Metodologis CLD KHI," [Methodological Argument of the CLD of KHI] in Kompas, 7 March.

${ }^{16}$ Tim Pengarusutamaan Gender, Pembaruan Hukum Islam, p. 9. 
instruments of human right like the Universal Declaration of Human Right (1948) and ICCPR (International Covenant on Civil and Political Rights) (1966). ${ }^{17}$

According to the TGM, studying the Compilation from the sociological view bears a conclusion that the material configuration within it has not been fully contextualized with the Indonesian outlook, but more represents a fiqh configuration in the Middle Eastern countries. The Compilation does not really accommodate demands and needs of Muslims in Indonesia because of not be inferred from the local knowledge of society. ${ }^{18}$ Whilst from the political perspective, the TGM stated that at least the Compilation has four specific characteristics of law as a result of the political influence. First of all, looked from the strategy of law building, the character of the Compilation is semi-responsive because only did the judicative power (the Supreme Court) and the executive power (MORA) participate, meanwhile the legislative power (DPR) as a formal representative of Indonesian people was not involved. The representation of Muslim community through the Council of Indonesian Ulama' and a number of Muslim intellectuals in the Islamic higher education institutions was on the peripheral position. Secondly, from a view of its law material, the Compilation is characterized as an autonomous, reductionism, and conservative law. In other words, the substances of the Compilation are admitted as Islamic jurisprudence but with legislating for its small part (marriage, inheritance and endowment). Thirdly, from its implementation perspective, the Compilation has a character of facultative so it has no power to force every single citizen to carry out its rule of law. Fourthly, from its law purpose angle the Compilation which has a character of regulative and legitimist is inclined to be technical procedural and practical operational than strategic theoretical and conceptual. Besides that, the substances tend to justify the previous law products and institutions made by the state, like the Office of Religious Affairs (Kantor Urusan Agama), Religious Courts, and so

\footnotetext{
${ }^{17}$ Ibid.

${ }^{18}$ Ibid.
} 
on. Briefly, the norms of Islamic law in the Compilation have shifted from the authority of divine law to the authority of state law. ${ }^{19}$

The arrangement of the Counter Legal Draft of KHI is aimed at offering a new formulation of Islamic law which fits to the democratic life and reflects genuine characters of Indonesian culture. This draft is expected to be an alternative answer instead of the call for formalization of Islamic law on the one hand and the necessity to establish values of democracy in the nation state Indonesia. $^{20}$ Apart from critically studying some weaknesses within the Compilation, this idea was also inspired by the reality of a number of Muslim thinkers who review some irrelevant points in fiqh doctrines for they are an outcome of era, culture, and social imagination which is different from what happens today. Classic figh has a problem of not only irrelevant materials it contains, but also paradigm of which it stands. For instance, figh is always understood as knowing practical divine law inferred from theorem of the Qur'an and Sunnah. This understanding leads to make the truth of fiqh normative. Eventually the truth of fiqh is not measured by how far it can give goodness and benefits (mashlaha) for human being but by how far it refers textually to the Qur'an and Hadîth. This epistemology than becomes a way of thinking for literalistic group.

The modification of tenet certainties seems very important when we deal with particular verses, such as polygamy, inter-religious marriage and inheritance, penal law, and others. Those particular verses have become a part of problem in the discipline of Islamic law in which the procedure of tanqîh is used to solve the problem.

\section{Responses of Society as an Emerging Public Sphere}

As I have described in the foregoing part, the appearance of the Counter Legal Draft raised various reactions, comments, critiques, and appreciation. Those responses come not only from the social religion institutions, such as Nahdlatul

\footnotetext{
${ }^{19}$ Ibid., p. 11.

${ }^{20}$ Ibid., p. 4.
} 
Ulama', Muhammadiyah, or Majelis Mujahidin Indonesia, but also from every single Muslim scholar who concerns the issue of family law reform in Indonesia. Apart from that, the emerging debates relating this issue show us on the reality that the establishment of Islamic law in Muslim countries, mostly the family law, can be necessarily approached from a perspective of social discourse, not only as a political phenomenon. Besides that, the intensity of debates is an indicator of the development of a new public sphere in Indonesia. ${ }^{21}$

Simply, the responses can be categorized into two groups. Those who voice the necessity of family law reform and those who view that a reform meant is strengthening the law materials in the Compilation or raising its status to be a law which has a higher status in the hierarchy of Indonesian legal system.

First of all, appreciations expressed in reacting to this idea to a great extent come from reformists and academicians who have been concerning with the urgency of modern approaches employed in the reformation of Islamic law. According to them, besides normative source texts in Islam, the reality of social life must be taken into account in finding a formulation of law. Hence, sociological, anthropological, gender, and even political approach cannot be leaved.

Abu Rokhmad, a lecturer at IAIN Walisongo Semarang, in his article "KHI dan Gerakan Kesetaraan Gender" [KHI and the Movement of Gender Equality] said that the CLD of KHI is an attempt to respond the bill of Applied Law of Religious Courts in which the Compilation is used as its raw material. The weakness side being in the Compilation related to the inheritance law that gives disadvantages to women must be changed with a more compatible rule. In the case of polygamy for instance, the Compilation allows it with applying strict requirements. The CLD of KHI explicitly prohibits Muslims from polygamy

${ }^{21}$ For a discussion a public sphere in the different context, Morocco, can be read further in Léon Buskens (2003), "Recent Debates on Family Law Reform in Morocco: Islamic Law as Politics in an Emerging Public Sphere" in Islamic Law and Society 10 (1), pp. 70-131. See also Pauline Johnson (2001), "Habermas's Search for the Public Sphere" in European Journal of Social Theory 4 (2, pp. 218. 
based on the logic argumentation. ${ }^{22}$ Maria Ulfah Anshor, a chairwoman of youth women organization in NU, Fatayat, 2000-2004, said that Indonesian society is not ready to face changes and diversities. Therefore, disseminating the idea of gender equality in Islam needs a proper media. For well educated people, controversy over the CLD of KHI issue should be a forum for arguing each other, while for public society, the idea should be accompanied by a manual including an explanation of normative sources and mentioning the references of each issue offered. $^{23}$

Besides that, Ridwan, a lecturer at STAIN Purwokerto, in his book Membongkar Fiqh Negara [the Deconstruction of State Fiqh] described that the discourse of family law reform in Indonesia, especially the CLD of KHI, must be set in the academic context. The epistemological and methodological framework employed in the marriage and inheritance law hits the normativity and touches crucial matters. Nonetheless, the CLD of KHI is an attempt to keep the consistency of the renewal of Islamic law, inspired by the Compilation, based on the principle of continuity and change. ${ }^{24}$

Nasarudin Umar, a Professor at UIN Syarif Hidayatullah Jakarta accounts a positive side in developing idea of the CLD of KHI, i.e., asking public society to rethink, as a shock therapy, and opening a new horizon for society. However, the negative effect, confusion of ideas for society, must also be noted. ${ }^{25}$ In the same spirit as Ridwan's opinion, Mochamad Sodik, a lecturer at UIN Sunan Kalijaga, said that the CLD of KHI is an alternative of the rigidity of Indonesian fiqh which is experienced by a couple of society and woman activists. Among the existing controversies over this issue, the academic world ought to react in the discursive courage to not a priori accept and reject the idea fully. Nevertheless, the humanity

22 Abu Rokhmad (2005), "KHI dan Gerakan Kesetaraan Gender," [KHI and the Movement of Gender Equality] in Suara Merdeka, 26 February.

23 Maria Ulfah Anshor (2004), "Pro Kontra Counter Legal Draft KHI Harus Dijembatani," [Pro and Contra over CLD of KHI Must be Bridged] in Kompas, 18 October.

${ }^{24}$ Ridwan (2005), Membongkar Fiqh Negara: Wacana Keadilan Gender dalam Hukum Keluarga Islam, [the Deconstruction of State Fiqh: A Gender Equality Discourse in the Islamic Family Law], Yogyakarta: Unggun Religi, pp. 209-210.

${ }^{25}$ Nasaruddin Umar, "Tak Ada yang Baru dalam Counter Legal Draft KHI," [Nothing New in the CLD r of http://www.nu.or.id/data_detail.asp?id_data=4017\&kategori=WARTA 
spirit within the CLD of KHI should be balanced by an attitude and diction of good statements. The statement of an "ancient" fiqh to call classic fiqh is necessarily avoided. ${ }^{26}$

Secondly, on the contrary of pro group, the strong reactions to the CLD of KHI for the large part come from ulama' on behalf of their religious social organization though there are also a number of opinions represent individuals of Muslim scholars. It was the Council of Indonesian Ulama (Majelis Ulama' Indonesia) who responded this draft by giving a statement "This is a devil law". ${ }^{27}$ Furthermore, the Fatwa Commission of MUI in the Ulama' Conference or Ijtima' Ulama held in the modern pesantren of Gontor, East Java, from 24 to 27 May 2006 stressed its attitude to support the bill of the Applied Law of Religious Court. MUI also recommend the government to quickly legislate for this bill to be the law. ${ }^{28}$

Besides that, Majelis Mujahidin Indonesia (MMI) argued that the Counter Legal Draft of KHI is ambitious to deconstruct sensitive laws. In the marital case, the practice of polygamy is prohibited and a woman can marry herself. Even, this organization sent an invitation to the TGM to have a debate. ${ }^{29}$ A professor of Islamic law at the University of Indonesia, Tahir Azhari, considered some points in the draft as an imagination. On the temporary marriage, he explained that a marriage must be built on the law not only on the contractual agreement. ${ }^{30} \mathrm{~A}$ negative view was said by Nabilah Lubis, a professor at UIN Jakarta. She said that the law 1/1974 on the marriage and the Compilation of Islamic Law are still relevant and capable enough to accommodate the societal interests. The materials contained in the law and the Compilation have been appropriate with the Islamic norms. What offered in the CLD of KHI, such as the same portion of inheritance

\footnotetext{
${ }^{26}$ Mochamad Sodik (2004), "Mencairkan Kebakuan Fikih: Membaca KHI dan CLD KHI bersama Musdah Mulia," [Liquefying the Rigidity of Fiqh: Reading KHI and the CLD of KHI with Musdah Mulia] in As-Syir'ah 38 (2), pp. 194-211.

${ }^{27}$ Tempo, edition 11-17 October 2004.

${ }^{28} 19$ Fatwa of MUI, quoted from http://www.halalguide.info/content/view/197/40.

${ }^{29}$ Muhammad Thalib: "Draft KHI Versi Gender Lecehkan Syari'at Islam," [the Draft of Gender Version $\quad$ KHI Insults Islamic Shari'a] in http://www.hidayatullah.com/index.php?option=com_ content\&task=view $\&$ id $=1451 \&$ Itemid=0 accessed on 7 September 2005.

${ }^{30}$ Republika, 5 October 2004.
} 
for both man and woman and the decision of 'iddah for husbands contradicts the principle of Islam. $^{31}$

A figure of Hizbut Tahrir Indonesia organization, M. Shidiq al-Jawi said that the Counter Legal Draft of KHI does not truly reflect Islamic law, but does express the ideology of capitalism. In other words, it is a media of foreign values occupation over Indonesian muslim society wearing a mask of Islamic law. Distinctively, it is a tool of Western colonialism in the field of Islamic family law. $^{32}$

A refutation to the CLD of KHI also comes from Al-Majlis al-'Alami li 'Alimat al-Muslimat (MAAI) or the International Council of Muslimah Intellectuals in a discussion to celebrate its $5^{\text {th }}$ year and the book launching of Huzaemah Tahido Yanggo. ${ }^{33}$ There were seven recommendations produced in that forum. One of them says that the CLD is a grand strategy to break Islam in Indonesia. The CLD will never raise the position of Indonesian women, however extremely it will destroy family lives.

Research done by the writer in 2006 to know the response of ulama' of Nahdlatul Ulama' and Muhammadiyah in Yogyakarta over the CLD of $\mathrm{KHI}^{34}$ can be summed up into three major points. First of all, they agree to that the renewal of Islamic law which not only relies on the classic fiqh is an unavoidable agenda, even to some extent becomes a must in regard to the changes in the society. In addition, the being developed Islamic law in Indonesia should rest on contextualizing text reality both in the Qur'an and Hadîth on the empirical realities within Indonesian society. Consequently, the forth progression of fiqh in

${ }^{31}$ Nabilah Lubis (2005), "Peran Suami Istri Sama dalam Perkawinan," [the Role of Husband and Wife in Marriage is Equal] in Dialog Jum'at (Tabloid Republika), 24 June.

${ }^{32}$ M. Shiddiq al-Jawi (2004), "Menyoroti Draft KHI dari Perpektif Ideologis dan Metodologis (1)," [Gazing upon Draft of KHI from the Ideology and Methodology Perspective] in Suara Muhammadiyah, No. 23 the $89^{\text {th }}$ year, 1-15 December, pp. 38-39; M. Shiddiq al-Jawi, "Menyoroti Draft KHI dari Perpektif Ideologis dan Metodologis (2) (2004)," in Suara Muhammadiyah, No. 24 the $89^{\text {th }}$ year, 16-31 December, pp. 38-39

33 "Kompilasi Hukum Islam Revisi yang Dikoreksi" [A Corrected Revision of the Compilation of Islamic Law] in Republika, 18 February 2005.

34 Muhammad Latif Fauzi (2006), "Pandangan Ulama' Nahdlatul Ulama' dan Muhammadiyah terhadap Counter Legal Draft Kompilasi Hukum Islam: Studi di Yogyakarta”, [The View of Ulama' of NU and Muhammadiyah over the CLD of KHI: Study in Yogyakarta], thesis at the Postgraduate Programme of UIN Sunan Kalijaga Yogyakarta. 
Indonesia will be an endeavour to legislate and codify the norms of Islamic law which fit into the entire element of society in whatever their religion is.

Secondly, related to the approach of the CLD of KHI, they affirm the necessary of utilizing a justice perspective approach because a contextual understanding actually has been practiced by ulama' since the era of companions up to now. However, the big problem remains at on the one hand how to be aware of idea diversities which always escort and on the other hand how the best method to spread this idea out. Thus, this condition ought to be taken to the more productive area, revitalizing the diversity to build a more adaptive to all interests. The big narration of the contextualization of Islamic law and the agenda of its reform is certainly interpreted concretely in the social life.

The last, in connection with the method of the CLD of KHI, it can be concluded that the stagnancy of the thought of Islamic law is caused by the principle of legal theory which was hold by a majority of ulama' under the domination of scholastic thinking. If so, is it enough to simply revitalize marginal principles and marginalize mainstream principles? If it is not, the parameter of the principles is the social reality. Hence, forging a new methodology capable of analyzing complicated social phenomena on the one hand and facilitating the derivation of rules and concepts from revelation on the other is one of the paramount concerns of contemporary Islamic scholarship definitely needed.

Sorrowfully this idea was finally interdicted by the Minister of the MORA by issuing two letters, MA/271/2004 and MA/274/2004. These two letters substantially contain a warning to the TGM to not conduct seminars on behalf of the MORA and an explanation of that the MORA never formed the TGM. This decision to my mind has bothered the creating of a public space in which a society is probable to play a role in the process of legal and judicial reform. The government, the MORA in this case, should not interfere too deeply with this matter because establishing an optimistic, rational, and critical society in Indonesia is not a one night work.

\section{E. Dialogue and Communication as the Way to Create a Conducive Climate}


The above explanation shows us that the face of family law reform in Indonesia is dilemmatic and surrounded by a range of interests. Yes, the appearance of the Compilation is indeed one of articulations of family law reform in Indonesia. As a set of law, it was arranged based on the needs of society which simultaneously reflects the Islamic norms. The reformation spirit within the Compilation methodologically was formulated by method of mashlahah mursalah, 'urf, and talfîq (eclectic). This methodology emerges very clearly in the Compilation in order to accommodate the socio-cultural claim and harmonize a variety of isms and schools in the Islamic jurisprudence thought. However, regrettably the rapid development of science and modern knowledge creating more complex problems cannot be answered by the Compilation. Even the Compilation to what extent is becoming conservative due to its rigidness. Therefore, reducing the conservatism of the Compilation, the reformation is the only one solution.

Nevertheless, the condition is not as easy as it sounds. The emergence of the Counter Legal Draft of Kompilasi Hukum Islam which tries to fill the emptiness and to cover the weakness being in the Compilation is a brilliant idea. Additionally, the framework of epistemology and methodology employed is rational and logic. Unfortunately, though it must be placed as an academic discourse, in some aspects it has touched and hit the demarcation line of shari'ah which since long time ago has been kept and practiced in the religious courts. This is somehow the weakness of the CLD of KHI and consequently the society cannot perceive it easily.

With regard to the above rationalization, I presume that one problem which should be dealt with is a demand for a proper way in revitalizing the differences of opinion and how it is disseminated for public. These two problems are a must to consider. If so, to my knowledge, the proposal of law reform in Indonesia is frequently problematic on the communicative level. ${ }^{35}$ Here, conflict

${ }^{35}$ This idea was proposed by Jurgen Habermas, a philosopher and sociologist, expounded a critical theory of knowledge and human interests. He argued that human knowledge could be categorized as technical, practical, and emancipatory based on primary cognitive interests. He suggested that these areas are "knowledge-constitutive interests" because they determine 
of interest of society is often as the main problem. As a result, the planned reform cannot often walks effectively. In general, this tension roots from the different epistemological outlook toward permanency and temporality of Islamic law. Besides that, the various kinds of appreciation of the old tradition including the heritage of ulama' thought in the classic and medieval period is also the other factor.

Anyhow the great diversity of opinion within discourse of the Islamic scholarship is a treasure and wealth as an indication of an opened climate, tolerance, and appreciation among jurists and community of the plurality of religious understanding on the one hand. However, on the other, it must be taken into a consideration that such controversies to some extent bother the reformation process. Gazing at this reality, the best way to address this problem is establishing a space of dialogue to search for a consensus over existing opinions. In this context, Salahuddin Wahid emphasizes the importance of the dialogue with certain conditions as a part of solution. ${ }^{36}$ In addition to Wahid's, Khaeron Sirin while reacting to opinions regarding the fatwa issuance by the MUI, said that it is no reason for society, modernists Islam, to have a feeling of a priori or anxiety in imagining the future of religious life in Indonesia. The future of society is not a task encumbered to modernists Islam, however it is a work of the entire of Muslims, including the MUI. Thus, wherever Muslim society is, in there should be a dialogical gate conducted. Therefore, the appearance of the MUI's fatwas, in his opinion, becomes a source of learning and is educating and simultaneously

categories that humans interpret as knowledge. He wants to probe the deep linkages among knowledge, experience and human purpose. Especially in his book, Knowledge and Human Interests, and in some earlier commentaries what Habermas reveals is that the content of our thought is less important than the manner of our thought. Specific opinions can change or be changed but, beneath them, our epistemological assumptions frequently remain unchallenged. He argued that the interests are based on aspects of social existence, such as work, interaction, and power. He connected technical interests to work, practical interests to interaction, and emancipatory interests to power. Bev Taylor (2004), "Technical, Practical, and Emancipatory Reflection for Practicing Holistically," in Journal of Holistic Nursing 22 (1), p. 74; Howard A. Doughty (2003), “Jürgen Habermas' Concept of Universal Pragmatics: A Practical Approach to Ethics and Innovation," in The Ethic of Innovations 8 (4).

36 Salahuddin Wahid (2005), "Dialog, Sekali Lagi Dialog (Solusi Untuk “'Konflik Terbuka"' Pemimpin Umat)," [Dialogue, Again Dialogue: a Solution for the Open Conflict of Leaders] in Republika, 15 August. 
dialectical process for Islamic society to be more realized and aware of the importance to understand religious principles properly. This point is necessary in order to strengthen the identity and conviction of Muslims with an insight to implement and attain a civilized Islam in Indonesia. ${ }^{37}$

Bearing productive and compromised thinking needs a fair and reliable dialogue must be accompanied with encouraging all parties to perform self introspection, evaluation, and accomplishment toward their understanding. This idea sharing needs a public sphere which is not only designed physically but a social space which is resulted by communicative actions. Public sphere can be a place to build public opinion reflecting the developing issues at the elite and grass root level. Opinion building through establishing dialogical and debated process has a power (communicative power) to participate in the process of formal decision drawing. ${ }^{38}$

Furthermore, the reform planned should head for the emancipative social changes. It must light the society in order to act properly. Of course, the emancipation does not merely mean liberation from the social constraints, like an oppressive hegemonic power (the power of law and thought) but also liberation from the internal obstacles, such as ignorance and stupidity. The progression of public debate traditions concerning all aspects within social life indirectly can increase the learning capacity of learning people entirely and make them capable to be critical and mature in facing the reality of plurality and diversity. This situation to some extent will reduce the narrow primordial ideology and the absolute dependency on the rule of social figures that often trigger the emergence of horizontal conflict on behalf of religion.

It is obviously sure that building a condition which is comfortable and secure to hold a dialogue and communication is not an easy work. It does not just

37 Khaeron Sirin (2005), "Geliat MUI di Wacana Publik" [the MUI in the Public Discourse] in Republika, 8 August.

${ }^{38}$ The availability of a public sphere as a medium to express ideas in an equal position enabling people to establish a transaction of discourse and political practice without any distortion and anxiety is a condition to implement civil society. Furthermore see in John R. Bowen (1999), "Legal Reasoning and Public Discourse in Indonesian Islam," in Dale F. Eickelman and Jon W. Anderson (eds), New Media in the Muslim World: The Emerging of Public Sphere, Bloomington and Indianapolis: Indiana University Press, pp. 80-105. 
require a circumstance where people can have a deep understanding of plurality, act inclusively and may respect each other. It will be no meaning if the economic condition of a nation is not good and suitable to conduct such dialogue. Therefore, Kees van Dijk reminds us that although communal violence which happened before the financial crisis struck in Indonesia, for there is no an attitude of understanding each other, was by no means a new phenomenon, it was suggested that economic growth adds a new dimension. However, he admits that reasons for the violence and no tolerance culture such as effects of economic development, the economic crisis, globalization, and the influence of the West are not enough explanation. ${ }^{39}$

\section{F. The Emergence of a Public Sphere and Creating Good Governance}

Gazing upon the above phenomenon, we may be very happy with the difference of opinions that exist. The writer is indeed optimistic as an agenda to reform the family law is perceived by society widely because of having established a public space enabling all participants to communicate their understanding. Nevertheless, it should be taken into an account that an understanding meant is that not based on egocentrism but on the activities to respect for each other. Thus, the orientation of the expected reform is not determined by how each group can concrete its goal but is examined by the concord of the individual activities and common situation definitions.

The participation of citizens in the public sphere blows fresh air for the process of democratization in Indonesia. The participation of civil society in a process of legal building, one of them is Islamic law reformation, to some extent gives a very positive signal to the establishment of good governance. In Habermas's theory for instance, the public sphere plays a key role: it is conceived as a dispersed, all-encompassing, discursive network within which citizens, connected by the means of mass communication, form currents of opinion in

\footnotetext{
${ }^{39}$ Kees van Dijk (2000), "Who Throws the First Stone?" in Andi Faisal Bakti (ed), Good Governance and Conflict Resolution in Indonesia, Jakarta: Logos, pp. 127-129.
} 
seeking how best to resolve common problems. ${ }^{40}$ Patrizia Nanz and Jens Steffek note that s public understood as a collectivity of persons connected by processes of communication over particular aspects of social and political life may extend beyond national borders. note that what is important to the notion of public deliberation is not so much that everyone participates but more that there is a warranted presumption that public opinion is formed on the basis of adequate information and relevant reasons, and that those whose interests are involved have an equal and effective opportunity to make their own interests known. ${ }^{41}$

In good governance, participation and empowerment are self-reinforcing and surely no society can have one without the other. Good governments must emphasise participation and responsiveness in the relation between governors and the governed at all levels. ${ }^{42}$ Participation seems to mean different things for different people. In the realm of development, participation is sought to render unique institutional support that should ideally enhance cost saving, efficiency and self-help. In a free market-driven participation, the overall objective is understood as the public sector's cost-sharing and cost reduction for the. However, it could also be understood as an effective instrument to ensure effective citizen struggle for inclusion, civil, economic and political rights, including democracy. As an effective instrument available to the poor, participation is better understood in terms of "access to decision making and power."43

Democratic governance and participation alone cannot guarantee that citizens have been empowered for effective participation. Thus, empowerment affirms the need to enable people measure the reality of their political, social, economic and physical environment in order to influence these factors.

\footnotetext{
${ }^{40}$ Jürgen Habermas (1996), Between Facts and Norms, Cambridge, MA, MIT Press, p. 360.

${ }^{41}$ Patrizia Nanz and Jens Steffek (2004), "Global Governance, Participation and the Public Sphere," in Government and Opposition 39 (2), pp. 320-321.

${ }_{42}$ Ibrahim Abu Shah (2004), "Democracy and Good Governance: Ideas and Institutions" in Ibrahim Abu Shah (ed.), Islam, Democracy and Good Governance: The Malaysian Experience, Shah Alam, UPENA, p. 10

${ }^{43}$ Mohammed Salih (2003), "Governance, Information and the Public Sphere", paper presented at the $3^{\text {rd }}$ Meeting of CODI, Economic Commission for Africa, Addis Ababa, 10-17 May, p. 13.
} 
Empowerment cannot be realised in abstract terms or without identifying the necessary conditions for its success. While democratic governance, provides the necessary overall conditions within which empowerment is potentially achievable through access to five concrete dimensions: participation, knowledge, skills and new capabilities, freedom of information, regulatory institutions of the state, and income, land and other resources. These all factors for good governance are interrelated and cannot be separated one another.

In a more current analysis, Cornwall and Gaventa developed a model of the link between citizen, social and political participation in effective participatory method. This could be summarized follows: ${ }^{44}$

"Where citizens have been able to take up and use the spaces that participatory processes can open up, they have been able to use their agency to demand accountability, transparency and responsiveness from government institutions. An informed (referring to availability of adequate and reliable information, emphasis added), mobilised citizenary is clearly in a better position to do so effectively; the capacities built through popular education on rights and responsibilities also extend beyond taking a more active interest in seeking responsiveness and have only listened to but not acted upon citizens concerns...these moves offer new spaces in which the concept of participation, linking participation in the political, community and social spheres."

Ending this discussion, it is very interesting to cite a closing statement of Kees van Dijk as he said that what it is all about is the creating of an atmosphere in which good governance can be implemented. ${ }^{45}$ In other words, the proposal for Islamic law reform which gives a broad space to society to appear before the stage of democratization should be struggled. This public sphere to some extent is

${ }^{44}$ Cornwall, A. and John Gaventa (2001), "Bridging the Gap: Citizenship, Partnership and Accountability," quoted from Mohammaed Salih (2003), "Governance, Information and the Public Sphere", p. 14.

${ }^{45}$ Kees van Dijk (2000), "Who Throws the First Stone?", p.129. 
aimed at protection of civil liberties, free speech, free assembly, and free press expedite access to information that enable citizens to assess the actions of government officials and of other citizens

\section{G. Concluding Remarks}

Although the dynamic relationship between good governance, the emergence of a public sphere, and the Islamic law reform is a complex and subject to differing views and interpretations, this relationship can be undertaken only when the overall political context within which they interact is governed by the ethos and core values of democratic governance. However, this relationship is embedded in the political culture that informs the dominant political institutions of a society. These are reaching relations in which education, social capital, integrity, trust, the quest for justice are probably more important than driven projects and simplistic technical solutions from the government.

Engaging the public sphere in this complex relationship preludes to involving society in its entirety in order to establish good governance and simultanouslty make government worthy of the trust of very citizens. The reformation of family law in Indonesia which was begun about twenty years ago and is coloured by the emergence of conflicts and tensions is a good example to be concerned. The reformist intellectual group, the Team of Gender Mainstreaming, an alternative draft called 'the Counter Legal Draft of Kompilasi Hukum Islam', and a range of responses and reactions are a fascinating condition to rebuild a culture of unity in diversity. But, it is very disappointing that the Minister of the MORA issued a decision to interdict this discourse.

Looking at the content of debates and considering some opinions of Muslim intellectuals, I have assumed that the proper way to revitalize the differences of opinion and how these ideas should be disseminated for public are things which need a way out. Since this matter connects with the conflicts and tensions of interest, the government has to provide an enough space of dialogue to search for a consensus over existing opinions. The emergence of a public sphere to deal with the problem in the social level is the most possible way. Finally, it is 
not to exaggerate to say that the creating of a public sphere in a society is an incredibly wealthy capital to maintain the implementation of good governance in Indonesia. 


\section{BIBLIOGRAPHY}

Abd Moqsith Ghazali (2005), "Argumen Metodologis CLD KHI," [Methodological Argument of the CLD of KHI] in Kompas, 7 March.

Abdullah Ahmed an-Nai'm (2002), "Shari'a and Islamic Family Law Transition and Transformation," in Islamic Family Law in a Changing World: A Global Resource Book, Abdullah Ahmed an-Na'im, ed., London: Zed Book.

Abu Rokhmad (2005), "KHI dan Gerakan Kesetaraan Gender," [KHI and the Movement of Gender Equality] in Suara Merdeka, 26 February.

Asian Development Bank (1999), "Good Governance and Anti Corruption: The Road Forward for Indonesia", paper presented at the $8^{\text {th }}$ Meeting of the Consultative Group on Indonesia, Paris 27-28 July.

Bev Taylor (2004), "Technical, Practical, and Emancipatory Reflection for Practicing Holistically," in Journal of Holistic Nursing 22 (1).

Daniel Genberg (2002), "Public Space Inside Out: Beirut's Private and Public Spaces Under Reconstruction," in Eva Poluha and Mona Rosendahl, Contesting Good Governance: Crosscultural Perspectives on Representation, Accountability and Public Space, London: Routledge Curzon.

Daniel S. Lev (2000), "Reformasi?" in Andi Faisal Bakti (ed), Good Governance and Conflict Resolution in Indonesia, Jakarta: Logos.

Dewi Fortuna Anwar (2001), "Pluralism and Good Governance" in International Journal on Minorities and Group Rights 8.

Howard A. Doughty (2003), “Jürgen Habermas' Concept of Universal Pragmatics: A Practical Approach to Ethics and Innovation," in The Ethic of Innovations 8 (4).

Ibrahim Abu Shah (2004), "Democracy and Good Governance: Ideas and Institutions" in Ibrahim Abu Shah (ed.), Islam, Democracy and Good Governance: The Malaysian Experience, Shah Alam, UPENA.

John R. Bowen (1999), "Legal Reasoning and Public Discourse in Indonesian Islam," in Dale F. Eickelman and Jon W. Anderson (eds), New Media in the Muslim World: The Emerging of Public Sphere, Bloomington and Indianapolis: Indiana University Press.

----- (2003), Islam, Law and Equality in Indonesia: An Anthropology of Public Reasoning, Cambridge: Cambridge University Press.

Jürgen Habermas (1996), Between Facts and Norms, Cambridge, MA: MIT Press,.

Kees van Dijk (2000), "Who Throws the First Stone?" in Andi Faisal Bakti (ed), Good Governance and Conflict Resolution in Indonesia, Jakarta: Logos. 
Khaeron Sirin (2005), "Geliat MUI di Wacana Publik" [the MUI in the Public Discourse] in Republika, 8 August.

Khoiruddin Nasution (2002), Status Wanita di Asia Tenggara: Studi terhadap Perundang-undangan Perkawinan Muslim Kontemporer di Indonesia dan Malaysia [the Status of Women in South East Asia: A Study of the Muslim Contemporary Marriage Laws in Indonesia and Malaysia], Jakarta: INIS.

Léon Buskens (2003), "Recent Debates on Family Law Reform in Morocco: Islamic Law as Politics in an Emerging Public Sphere" in Islamic Law and Society 10 (1).

M. Shiddiq al-Jawi (2004), "Menyoroti Draft KHI dari Perpektif Ideologis dan Metodologis (1)," [Gazing upon Draft of KHI from the Ideology and Methodology Perspective] in Suara Muhammadiyah, No. 23 the $89^{\text {th }}$ year, 1-15 December.

------, "Menyoroti Draft KHI dari Perpektif Ideologis dan Metodologis (2) (2004)," in Suara Muhammadiyah, No. 24 the $89^{\text {th }}$ year, 16-31 December.

Maria Ulfah Anshor (2004), "Pro Kontra Counter Legal Draft KHI Harus Dijembatani," [Pro and Contra over CLD of KHI Must be Bridged] in Kompas, 18 October.

Marzuki Wahid and Rumadi (2001), Fiqih Mazhab Negara: Kritik atas Politik Hukum Islam di Indonesia [State Fiqh: A Critique of Islamic Politic Law in Indonesia], Yogyakarta: LKiS.

Mochamad Sodik (2004), "Mencairkan Kebakuan Fikih: Membaca KHI dan CLD KHI bersama Musdah Mulia," [Liquefying the Rigidity of Fiqh: Reading KHI and the CLD of KHI with Musdah Mulia] in As-Syir'ah 38 (2).

Muhammad Latif Fauzi (2006), 'Pandangan Ulama' Nahdlatul Ulama' dan Muhammadiyah terhadap Counter Legal Draft Kompilasi Hukum Islam: Studi di Yogyakarta", [The View of Ulama' of NU and Muhammadiyah over the CLD of KHI: Study in Yogyakarta], thesis at the Postgraduate Programme of UIN Sunan Kalijaga Yogyakarta.

Nabilah Lubis (2005), "Peran Suami Istri Sama dalam Perkawinan," [the Role of Husband and Wife in Marriage is Equal] in Dialog Jum'at (Tabloid Republika), 24 June.

Patrizia Nanz and Jens Steffek (2004), "Global Governance, Participation and the Public Sphere," in Government and Opposition 39 (2).

Pauline Johnson (2001), "Habermas's Search for the Public Sphere" in European Journal of Social Theory 4 (2).

Ridwan (2005), Membongkar Figh Negara: Wacana Keadilan Gender dalam Hukum Keluarga Islam, [the Deconstruction of State Fiqh: A Gender Equality Discourse in the Islamic Family Law], Yogyakarta: Unggun Religi. 
Salahuddin Wahid (2005), "Dialog, Sekali Lagi Dialog (Solusi Untuk "'Konflik Terbuka”" Pemimpin Umat)," [Dialogue, Again Dialogue: a Solution for the Open Conflict of Leaders] in Republika, 15 August.

Tahir Mahmood (1972), Islamic Law Reform in the Muslim World, Bombay: Triphathi Pvt.

Tim Forum (2004), "Poligami, Jangan... Kawin Kontrak, Silakan...," [Polygamy, No...Contract Marriage, Please] in FORUM Keadilan, no. 26, 24 October.

Tim Pengarusutamaan Gender (2004), Pembaruan Hukum Islam: Counter Legal Draft Kompilasi Hukum Islam [the Renewal of Islamic Law: the Counter Legal Draft of Kompilasi Hukum Islam], Jakarta: Depag RI. 